\title{
Inactivation of Escherichia Coli, Coliforms and Coliphages During Storage of Animal Wastes Under Tropical Climatic Conditions
}

\author{
Philbert Balichene Madoshi ${ }^{1,2, ~ *, ~ A m a n d u s ~ P a c h i f i c u s ~ M u h a i r w a ~}{ }^{2}$, Mkumbukwa M. A. Mtambo ${ }^{3}$, \\ Anita Forslund ${ }^{4}$ \\ ${ }^{1}$ Saint Francis University College of Health and Allied Sciences, Ifakara, Tanzania \\ ${ }^{2}$ Department of Veterinary Medicine and Public Health, College of Veterinary Medicine and Biomedical Sciences, Sokoine University of \\ Agriculture, Morogoro, Tanzania \\ ${ }^{3}$ Tanzania Industrial Research Developments Organisation, Dar es Salaam, Tanzania \\ ${ }^{4}$ Department of Veterinary and Animal Sciences, Food Safety and Zoonoses, University of Copenhagen, Copenhagen, Denmark
}

Email address:

bmadoshi@gmail.com (P. B. Madoshi), muhairwa@yahoo.com (A. P. Muhairwa), mtambo@yahoo.com (M. M. A. Mtambo), anf@sund.ku.dk (A. Forslund)

${ }^{*}$ Corresponding author

\section{To cite this article:}

Philbert Balichene Madoshi, Amandus Pachificus Muhairwa, Mkumbukwa M. A. Mtambo, Anita Forslund. Inactivation of Escherichia coli, Coliforms and Coliphages During Storage of Animal Wastes Under Tropical Climatic Conditions. Frontiers in Environmental Microbiology. Vol. 7, No. 1, 2021, pp. 35-43. doi: 10.11648/j.fem.20210701.15

Received: November 23, 2020; Accepted: December 15, 2020; Published: March 12, 2021

\begin{abstract}
Background: Animal waste management in the peri-urban and urban settings in the developing countries is hampered by the lack of proper handling of such wastes. The current methods of animal waste handling are based on common practices without considering the impact caused by such wastes in the public health. As a result such wastes are handled as other house garbage and disposed haphazardly in the environment including water bodies. This affects the quality of water for home consumption; contributing to air and environmental pollution and spread of enteropathogens to the public. Objective: Establishing suitable treatment method so as to increase the rate inactivation faecal indicator bacteria as model for management animal waste pathogens under the tropical conditions. Method: Cattle dung was treated basing on conventional heap (farmers practice), semi-aerated heap, semi-anaerobic heap, and modified (aerated) heap, where the dung was stored on a metal mesh, allowing free aeration from below and sides. Cattle waste indigenous $E$. coli, other coliforms and coliphages were enumerated as a function of treatment and time to determine the inactivation rate $\left(\mathrm{T}_{90}\right)$. Result and conclusion: Temperature and $\mathrm{pH}$ values in heaps were measured on each day of sampling, while \%DM values were calculated on day 0,21 and 50 . On average, coliphages declined more rapidly than $E$. coli and other coliforms in all treatments. The $\mathrm{T}_{90}$ values varied significantly between treatments $(p$ $<0.001)$ for $E$. coli and other coliforms $(p<0.01)$, with the aerated heap as the most effective with regard to inactivation and the semi-anaerobic heap as the poorest. In contrast, there was no statistical significant difference in coliphage inactivation $(p>0.93)$ with respect to treatment. Storage of cattle waste on metal-mesh in the tropical climate allows optimal aeration resulting into improved inactivation of indicator bacteria. It is recommended that more studies are carried on involving typical farmers' waste management practise, for the betterment of the environment and the public in general.
\end{abstract}

Keywords: Bacteriophages, Peri-urban, Heaping, Livestock, Coliphages

\section{Introduction}

In many developing countries, livestock keeping, and thus animal waste management, has increased significantly in townships, calling for immediate action to prevent the risk of pathogen spread between livestock and humans [1-3]. This includes the promotion of proper waste management practices; this is because most of the livestock wastes contain pathogens, which can survive in waste material for a relatively long time, 
yet they are disposed in the environment in an untreated form $[4,5]$. The released pathogens can enter into the water cycle, resulting in increased risk for environmental spread of pathogens [6]. Concurrently majority of pathogens can be inactivated by biological methods, which are cost effective and conserve, or even increase the nutritional value of the waste [7]. Temperature, aeration and duration of storage of the waste in a heap are fundamental factors for effective pathogen elimination [2, 8, 9]. Meanwhile increased inactivation of pathogens can be achieved by simple storage of waste in a form which allows optimal oxygen availability. Importantly, the resulting process preserves nutrient availability e.g. nitrogen and phosphorous, while eliminating protozoan enteropathogens such as Giardia and Cryptosporidium [10-12]. This is hard to achieve in the poor resource communities because there are no affordable ways to obtain optimal aeration, and hence farmers in tropical countries are left to heap the waste, without active aeration than what is provided by the straw material in the heap.

The detection of all enteropathogens in organic waste could be expensive and time-consuming; hence faecal indicator bacteria have been used extensively to evaluate pathogen contamination and elimination $[10,13,14]$. These organisms are easy to quantify, their handling requires less biosecurity measures than infectious pathogens, and there is no need of enriching the media during isolation, since they occur abundantly in animal waste [13-15]. The WHO [16] and ISO [17] advocate the use of faecal coliforms to evaluate contamination of water and environment by bacteria of human or animal origin.

In addition to the faecal coliforms there are groups of faecal bacteriophages that infect the faecal indicator bacteria such as coliphages for $E$. coli; these are somatic and F-specific phages which share fundamental properties and characteristics of enteric viruses in terms of morphology, size and replication. The phages can be valuable surrogates for indication of enteric viral concentration in water and waste, since their methods of quantification are cost effective, easy and reliable $[17,18]$ in addition they are distributed in all animal species [19]. Furthermore they outnumber the enteric viruses in the environment due to their resistance to unfavourable conditions and disinfection processes [20, 21]. The isolation of coliphages is based on the use of laboratory mutant of E. coli strain (ATCC 13796) which is hostile to most phage nucleic acids, due to the absence of $\mathrm{O}$ antigen and nuclease genes [21]. Thus their enumeration studies are relatively feasible to undertake, meanwhile inactivation of enteric virus in animal waste is technically demanding because their concentration in the environment is low [19, 22]. The prevalence of phages infecting E. coli $\mathrm{O} 157: \mathrm{H} 7$ (coliphages) have been determined in different animal waste samples by other authors [23-25]. The coliphages persist in the environment, and are easier to detect than eukaryotic viruses, as they can grow in common bacterial cultures as countable plagues $[22,25]$. Thus, inactivation of coliphages can be used as an alternative approach for quantifying inactivation of gastro-enteric viruses in such samples.
The current recommendation on storage time for animal waste, whether in aerated or non-aerated form, is based on inactivation studies carried out under temperate climatic conditions. Since temperature is such an important factor for pathogen inactivation in such geographical locations $[8,2]$, the rate and extent of pathogens reduction under those conditions may not be relevant for livestock keeping in (hot) tropical regions. It has been previously reported that the majority of cattle dung in urban and peri-urban areas in Tanzania is spread on crops or horticultural fields without treatment, thus increasing the risk for pathogen transmission to humans [26, 27]. This study aimed at determining the efficacy of eliminating bacteria and phages by simple waste treatment methods under tropical conditions in peri-urban areas, where farmers are constrained with plot size. In particular the study intended to investigate a simple way of increasing pathogen elimination by optimal aeration during storage.

\section{Methodology}

\subsection{Site Preparation}

The study was carried out in Morogoro, Tanzania is located between latitude $5^{\circ} 58^{\prime \prime}$ and $10^{\circ} 0^{\prime \prime} \mathrm{S}$ and longitude $35^{\circ} 25^{\prime \prime}$ and $35^{\circ} 30^{\prime \prime} \mathrm{E}$ where the ambient temperature ranges between $18^{\circ} \mathrm{C}$ and $30^{\circ} \mathrm{C}$. Solid cattle manure was freshly collected $(<72 \mathrm{hr}$ post deposition) from animal houses in four different locations. In order to imitate typical farm treatment strategies, the wastes were not subjected to any form of pre-treatment before their storage, care was taken to minimise aeration during loading, transit and mixing. The dung was piled in cubic $1 \mathrm{~m} \times 1 \mathrm{~m} \times 1 \mathrm{~m}$ storage silos and left to decompose for 50 days adopted from Mahfooz et al. [28]. The cubes were made of timbers in duplicates; one set was set on the ground and fully covered with polythene material to be regarded as semi-anaerobic; a second set was also set on the ground and constructed with timber with 2 inches left after each wood without polythene material cover to be regarded as semi-aerated.

The third set, which was the novel storage method, was built with metallic mesh wires and standing on a similar mesh $25 \mathrm{~cm}$ over ground to increase aeration termed as modified (aerated) heap. A traditional heap on the ground, similar to normal farmers practice, was included for comparison. Temperature and $\mathrm{pH}$ of dung in all treatments were recorded on each day of sampling. Measurements were performed as an average of three readings using $\mathrm{pH}$ metre (Corning $107^{\circledR}$ ) which is a dual device for measuring $\mathrm{pH}$ and temperature. In addition, $10 \mathrm{gm}$ of the waste was collected on day 0,21 and 50 for percentage dry matter (\%DM) determination, initially by weighing the crucible, waste with the crucible, then drying at $100^{\circ} \mathrm{C}$ for $18 \mathrm{hr}$. The remaining weight was expressed as the percentage of the initial weight as described by Hutchison et al [11].

\subsection{Sample Collection and Processing}

The physical parameters in additions to the number of $\mathrm{E}$. coli, other coliforms and coliphages as a function of storage 
time were assessed twice and in two cubes per treatment per time; in the wet season (March - April) and dry season (August - September) to include seasonal variations. Sampling was done on day 0, 1, 3, 7, 14, 21, 28, 35, 42 and 50, where three samples (surface, middle and bottom) were collected from each cube using modified sterile soil auger. The three samples were pooled to give one sample in each category. The samples were placed in a cool box and transported for analysis within $6 \mathrm{hr}$ of sampling.

\subsection{Bacterial Enumeration}

Ten gram of animal wastes were suspended in $90 \mathrm{ml}$ Maximum Recovery Diluent (Oxoid, Hampshire, UK), homogenized in mesh filter bags (6041/STR; Seward, Thetford, UK) placed in a stomacher (Colworth 400, Seward) for $1 \mathrm{~min}$ and centrifuged at $1300 \mathrm{~g}$ for $5 \mathrm{~min}$. The supernatant was filtered through a glass fibre $0.45 \mu \mathrm{m}$ (Sartorius 13430-0475; Sartorius, Apsom, UK) to remove particulates. One $\mathrm{ml}$ of the filtrate was diluted serially $10^{-1}$ to $10^{-7}$ in PBS, $100 \mu 1$ of the sample aliquot was pipetted into sterile petri dishes. On each Petri dish cooled molten $\left(45^{\circ} \mathrm{C}\right)$ Brilliance E. coli/Coliform Selective agar (Oxoid Ltd, Hampshire, UK) was poured. After the plates have solidified, they were incubated at $37^{\circ} \mathrm{C}$ for $24 \mathrm{hrs}$. Purplish blue and pinkish coloured colonies were counted as E. coli and other coliforms respectively. The colony counts were converted to $\mathrm{CFUg}^{-1}$ waste as described by International Standard organisation (ISO) [29].

\subsection{Somatic Coliphage Enumeration}

Escherichia coli (ATCC 25922) was used as host organism because it is a strain without hostile genes to most bacteriophages and it was preserved in $30 \%$ glycerol at $-80^{\circ} \mathrm{C}$ between trails. The phage enumeration was done by the double agar layer methods for phage enumeration as described by Adams [30]. The host bacteria was resuscitated on blood agar base (Oxoid, Hampshire, UK) and incubated at $37^{\circ} \mathrm{C}$ for $24 \mathrm{hr}$. A loopful of colonial mass ( 2 to 5 colonies) of the host strain was added to a $250 \mathrm{ml}$ bottle containing $100 \mathrm{ml}$ of nutrient broth (Oxoid, Hampshire, UK). The broth culture was incubated for $5 \mathrm{hr}$ at $37^{\circ} \mathrm{C}$ to give a cell density approximately $10^{8} \mathrm{CFUg}^{-1}$ which was comparable to 4.0 McFarland standards. The inoculum of the host bacteria was removed from the incubator and immediately cooled on melting ice for use on the same day.

Soft agar in $100 \mathrm{ml}$ portions was made by mixing $30 \mathrm{ml}$ of nutrient broth and $70 \mathrm{ml}$ of blood agar base. The mixtures were placed in a water bath at $45^{\circ} \mathrm{C}$. Thereafter $3 \mathrm{ml}$ portions were aseptically distributed into capped culture tubes. To each aliquot of soft blood and nutrient agar, $1 \mathrm{ml}$ of the serially diluted sample was added; on top of this, $1 \mathrm{ml}$ of inoculum culture of host bacteria strain was added. The resulting mixture was carefully mixed to avoid formation of air bubbles and poured on a layer of well-dried blood agar base petri dishes. The aliquot was distributed evenly and allowed to solidify and incubated at $37^{\circ} \mathrm{C}$ for $18 \mathrm{hr}$. The plaques were counted basing on clear zones formation on each plate and plaques forming unit of coliphage per gram $\left(\mathrm{PFUg}^{-1}\right)$ was calculated adapted from Forslund et al [31].

\subsection{Data Analysis}

The colony count of E. coli and other coliform bacteria and plaque count of coliphages were $\log _{10}$ transformed for normalisation and plotted against time. The best straight lines were fitted from the data using Stats Direct, (Chishire, UK) and from this a slope was obtained to calculate the decimation time $\left(\mathrm{T}_{90}\right)$. The $\mathrm{T}_{90}$ is the time required for a 1-log $(90 \%)$ reduction of the studied organisms, and corresponds to $1 /$ inverse slope of the inactivation line, as previously described by Hutchison et al. [32]. The $\mathrm{T}_{90}$ values of the indicator organisms (four treatments in duplicate in two seasons) were compared using one-way analysis of variance (ANOVA) with Tukey's post-hoc test. T-tests and mixed model analysis were used to test the independence of the readings in between and within treatments for further statistical inferences where $\mathrm{p}<0.05$ was used for statistical inference, using the Statistical Packages for Social Sciences (SPSS version 20).

\section{Results}

\subsection{Enumeration of Indicator Organisms in the Animal Wastes}

E. coli, other coliforms and coliphages, naturally occurring in cattle wastes, were subjected to four different treatment strategies. The waste were mixed before being placed into their respective treatment strategies and the mean $\mathrm{CFUg}^{-1}$ values of each initial concentration of indicator organisms in the different heaps were calculated. The $\mathrm{CFUg}^{-1}$ values of the study organisms in the waste were compared before treatment. It was observed that the $\mathrm{CFUg}^{-1}$ ranged from $7 * 10^{8}$ to $9 * 10^{9}$, and $4.3 * 10^{9}$ to $9.7 * 10^{9}$ for $E$. coli and other coliforms respectively, while the coliphages $\mathrm{PFUg}^{-1}$ was $5.6 * 10^{4}$ to $3 * 10^{5}$. It was statistically shown that the initial concentration of the microorganisms had no significant difference within treatments.

\subsection{Physical Parameter Variations in the Treatment Strategies}

The study was carried under natural settings, where the environmental factors (Temperature and $\mathrm{pH}$ ) were not controlled to imitate farmer's practices. Table 1 displays the means of $\% \mathrm{DM}$ of the wastes in the four treatments, on average the initial $\% \mathrm{DM}$ were $19.9 \%$ and $18.9 \%$ in the dry and wet season respectively. The final $\% \mathrm{DM}$ content at day 50 within the treatment was higher in the modified heap (MH) in dry $(27.6 \%)$ and wet $(25.6 \%)$ seasons but it was the lowest in semi-anaerobic heap (SANH) in dry $(21.6 \%)$ and wet season (20.9\%). However, statistically the \%DM of the waste showed no significant difference. Table 2 shows the mean temperature variations in both heaps and seasons, it is shown that the lowest and highest mean temperature values were $31.5^{\circ} \mathrm{C}$ and 
$37.5^{\circ} \mathrm{C}$ in the modified and conventional heap respectively.

Table 2 also shows the mean initial $\mathrm{pH}$ values, which were 7.3

and 7.1 in the wet and dry season respectively.

Table 1. The Dry matter percentage (\%DM) of the wastes in the dry and wet seasons.

\begin{tabular}{|c|c|c|c|c|c|c|}
\hline \multirow{3}{*}{ Treatment Strategy } & \multicolumn{6}{|c|}{ \%DM per Season on day 0,21 and 50* } \\
\hline & \multicolumn{3}{|c|}{ Dry } & \multicolumn{3}{|l|}{ Wet } \\
\hline & Mean \pm SD & Initial & Final & Mean \pm SD & Initial & Final \\
\hline MH & $24.3 \pm 3.2$ & 20.6 & 27.6 & $25.3 \pm 2.6$ & 18.9 & 25.6 \\
\hline $\mathrm{CH}$ & $22.7 \pm 2.1$ & 20.1 & 24.4 & $24.3 \pm 1.4$ & 19 & 23 \\
\hline SAH & $21.2 \pm 1.5$ & 19.7 & 22.8 & $23.3 \pm 1.3$ & 19.2 & 22.2 \\
\hline SANH & $20.6 \pm 1.0$ & 19.8 & 21.6 & $22.9 \pm 0.4$ & 19.1 & 20.9 \\
\hline
\end{tabular}

*Statistically there was no significant difference of the \%DM content between and within treatments and seasons.

Key: S. D=Standard deviation, MH - Modified heap, $\mathrm{CH}$ - Conventional heap, SAH - Semi-aerated heap, SANH - Semi-anaerobic heap

Table 2. Temperature $\left({ }^{\circ} \mathrm{C}\right)$ variations and $p H$ in the waste treatment strategies and seasons.

\begin{tabular}{|c|c|c|c|c|c|c|c|}
\hline \multirow{3}{*}{ Treatment strategy } & \multicolumn{6}{|c|}{ Temperature $\left({ }^{\circ} \mathrm{C}\right)$} & \multirow{3}{*}{$\begin{array}{l}\text { pH } \\
\text { Mean } \pm \text { SD }\end{array}$} \\
\hline & \multicolumn{3}{|c|}{ Dry } & \multicolumn{3}{|l|}{ Wet } & \\
\hline & Mean \pm SD & Min. & Max. & Mean \pm SD & Min. & Max & \\
\hline $\mathrm{MH}$ & $31.5 \pm 2.2$ & 28.0 & 34.9 & $36.2 \pm 4.0$ & 29.2 & 39.7 & $5.5 \pm 1.3$ \\
\hline $\mathrm{CH}$ & $37.6 \pm 3.6$ & 31.0 & 41.5 & $37.5 \pm 3.9$ & 29.2 & 40.2 & $6.1 \pm 1.1$ \\
\hline SAH & $35.8 \pm 3.9$ & 28.5 & 39.1 & $35.2 \pm 3.4$ & 30.0 & 39.5 & $6.2 \pm 0.8$ \\
\hline SANH & $38.9 \pm 3.4$ & 33.0 & 42.5 & $37.2 \pm 3.4$ & 32.0 & 40.5 & $7.0 \pm 0.3$ \\
\hline
\end{tabular}

Statistically, there was no significant difference within and in between treatments and seasons in terms of temperature and $\mathrm{pH}$ readings.

\subsection{Decimation Times (T90) for Indicator Organisms \\ During Waste Treatment}

Inactivation curves of the organism during the four treatments are shown in Figures 1, 2, and 3 for inactivation of $E$. coli, other coliforms and coliphages, respectively. It was assumed that the inactivation pattern followed the first order kinetics and the $T_{90}$ values were calculated using least mean square as previously described by Hutchison et al. [11] and Corradini and Peleg [33]. The season in which the experiment was conducted did not significantly influence the $T_{90}$ mean values (Table 3 ). The $\mathrm{T}_{90}$ values for $E$. coli were different with $p<0.001$ between treatments, while the $\mathrm{T}_{90}$ mean values were lower in modified heap (3.1 days) but higher in the semi-anaerobic ( 6.7 days). The inactivation of other coliforms also varied significantly between treatments $(p<0.01)$; the average $T_{90}$ values ranged between 5.4 and 7.7 days in the modified and semi-anaerobic heap respectively. The decimation time of coliphages in the four treatments was not statistically significant different $(\mathrm{p}<0.93)$ and the values were shorter when compared to $E$. coli and other coliforms in the semi-anaerobic heap and modified heap.

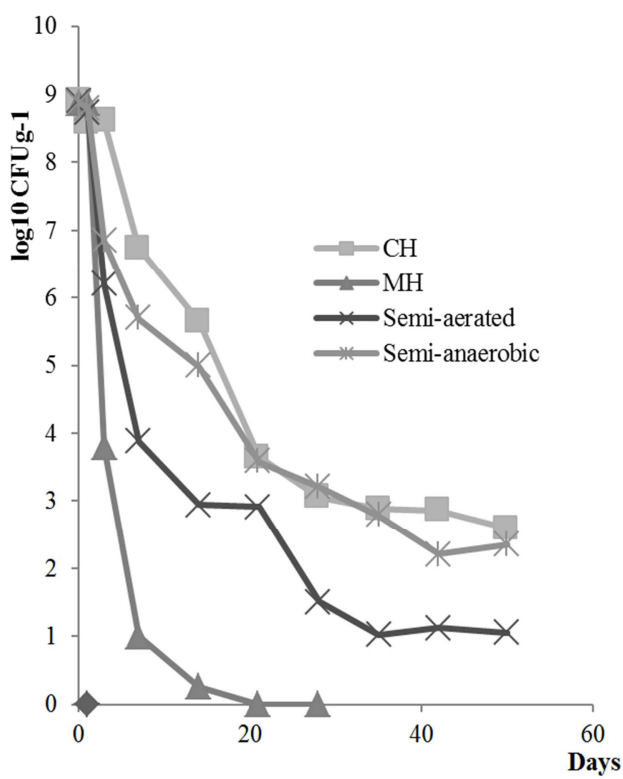

Figure 1. The inactivation of E. coli in all the treatment strategies, its decline is at the rapid rate in the modified compared to other treatment strategies $(p<0.001)$.

Table 3. $T_{90}$ (days) values for decimation of indigenous indicator organisms during cattle waste-treatment strategies

\begin{tabular}{llll}
\hline \multirow{2}{*}{ Treatment strategies } & \multicolumn{2}{l}{ T $_{\mathbf{9 0}}$ values (days) of the indicator bacteria (Mean \pm SD) } & Coliphages $^{\text {b }}$ \\
\cline { 2 - 4 } & $\boldsymbol{E}_{\text {. } \text { coli }^{\text {a }}}$ & Other coliforms $^{\text {a }}$ & $5.5 \pm 1.68$ \\
$\mathrm{MH}^{\dagger}$ & $3.1 \pm 0.09$ & $3.4 \pm 0.12$ & $5.6 \pm 2.96$ \\
$\mathrm{CH}$ & $6.2 \pm 0.10$ & $7.0 \pm 0.42$ & $4.8 \pm 0.65$ \\
$\mathrm{SAH}$ & $6.6 \pm 0.27$ & $6.4 \pm 0.28$ & $5.3 \pm 0.13$ \\
$\mathrm{SANH}$ & $6.6 \pm 1.52$ & $7.7 \pm 1.79$ & \\
\hline
\end{tabular}

The MH treatment was statistically significant different in the reduction of the tested microbes when the treatment strategies were compared. ${ }^{\mathrm{a}, \mathrm{b}}$ The studies organisms were also compared on the level and rate reduction within and between treatments, E. coli $(\mathrm{p}<0.001)$ and other coliforms $(\mathrm{p}<0.01)$ significantly declined compared to the coliphages $(\mathrm{p}=0.93)$. 


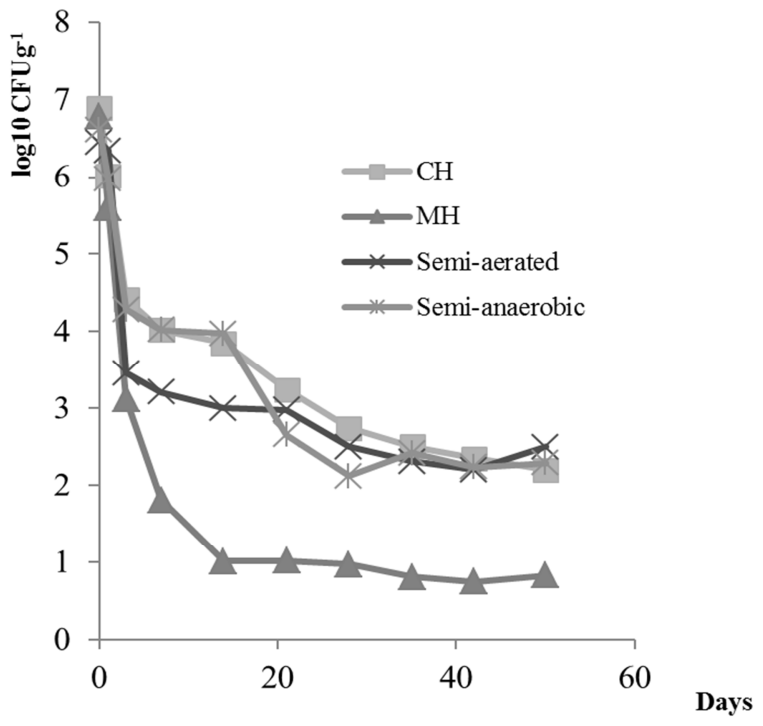

Figure 2. The inactivation of other coliforms in the four treatments was statistically significant different in the $M H(p<0.01)$.

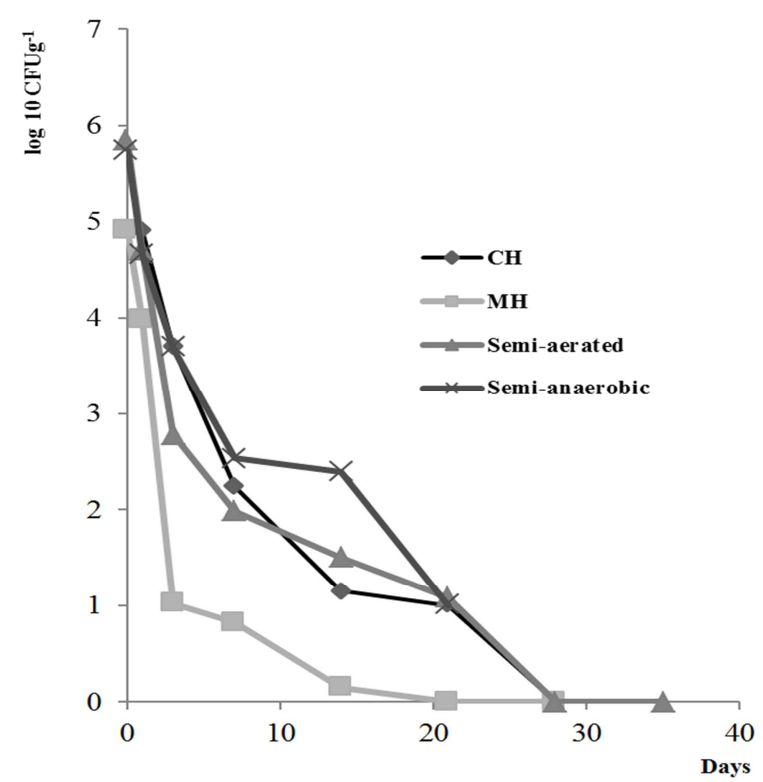

Figure 3. Coliphages inactivation in the four treatments was not statistically significant different in the four treatments ( $p=0.93$ ).

Key: CH - Conventional Heap, MH - Modified Heap, Semi-aerated heap, Semi anaerobic heap

\section{Discussion}

This study intended to evaluate treatments for transformation of animal wastes, which could lessen decimation time of enteropathogens in animal wastes, as compared to the traditional storage practice in most tropical livestock production of just heaping dung on the ground. The experiment was set under natural conditions to allow natural activity of the environmental factors within the heaps. The study clearly demonstrated that lifting the dung off the ground on a metal mesh resulted in increased inactivation of commensal E. coli and other coliforms, presumably due to improved aeration, while inactivation of the phages, as a proxy for virus, was not affected by the mode of treatment. Despite the fact that somatic coliphages are abundant in animal wastes, there are no comparable studies in Tanzania. Furthermore, this study only involved isolation and decimation of somatic coliphages thus the results did not compare the concentration of somatic versus F-specific coliphages. The decision on the use of somatic coliphages was based on the fact they outnumber the F-specific coliphages in various samples [19, 34, 35].

The coliphages in animal wastes have been quantified in many parts of the World to indicate the presence of enteric bacteria in the environment, water treatment and disinfection processes $[21,22,36]$. The coliphages $\mathrm{PFUg}^{-1}$ values in this study are in consistent to Dhillon et al. [37] who reported a concentration of coliphages $10^{1}$ to $10^{7} \mathrm{PFUg}^{-1}$ on samples from humans, cattle and pigs which were reared on common farms in Hong Kong. The study by Muniesa et al. [20] reported coliphages concentration in faecal polluted freshwaters to be $3.9 * 10^{4} \mathrm{PFU} / \mathrm{ml}$. Osawa et al. [34] reported a concentration of $10^{3}$ to $10^{5} \mathrm{PFUg}^{-1}$ in gastrointestinal content in Japan. However, the findings of the present study were higher than the results of Jung et al. [38] who reported the concentration of somatic coliphages on average to be 11 $\mathrm{PFUg}^{-1}$ in a study on phages as a substitute for microbial source tracking in Korean cattle. The results also showed that coliphages levels in the waste in all treatments on average declined within 6.8 days; although possibly, the decline was associated with the indigenous $E$. coli existence in waste. This could possibly be associated with the fact that the hosting bacteria in the waste were not plentiful enough to allow the existence of the phages.

The inactivation time of coliphages in this study is relatively higher compared to Kudva et al. [8] who reported 5 days inactivation of phages from $10^{9}$ to $10^{4} \mathrm{PFU} / \mathrm{ml}$ in bovine and ovine faeces treated at $37^{\circ} \mathrm{C}$. Cunault et al. [39] showed reduction of somatic coliphages in 10 minutes from $4.4 \log _{10}$ to $1.2 \log _{10}$ units when the temperature was varied from 55 to $60^{\circ} \mathrm{C}$. In comparison to the study by Pesaro et al. [40] who determined the inactivation of animal viruses and coliphages in semiliquid animal wastes, it was shown that coliphages are relatively thermal tolerant when compared to other enteric viruses. According to these authors, the decimation time of the coliphages was influenced by temperature where it was 7.1 days during the summer $\left(19.2^{\circ} \mathrm{C}\right)$ while it was 22.2 days at $10.1^{\circ} \mathrm{C}$ in winter. In addition, the decimation time $\left(\mathrm{D}_{90}\right)$ is influenced by waste type where according to their study the $\mathrm{D}_{90}$ was 3.3 days in liquid dairy cattle manure, while it was 17.4 days in the solid cattle manure when all the waste were kept under anaerobic digestions, these findings are in accordance to our results. In addition, Cunault et al. [39] used temperature and time to facilitate thermal inactivation of piggery effluents; the authors showed that increase in temperature to $70^{\circ} \mathrm{C}$ reduced the vegetative bacteria from 6.5 $\log _{10}$ to $4 \log _{10} \mathrm{CFU} / \mathrm{ml}$ within an hour.

E. coli, other coliforms and coliphages were found to be naturally occurring abundantly to allow evaluation of the 
decimation time in the waste. The ranges of indicator bacteria in cattle manure has been also reported by other workers [41, 42, 43]. Thurston-Enriquez et al. [41] reported $8.86 \pm 2.34$ $\mathrm{CFUg}^{-1}$ of coliphages and $7.85 \pm 2.84 \mathrm{PFUg}^{-1}$ coliforms concentration in fresh cattle faeces. On the other hand, the findings by us were high as compared to that of Klein et al. [42], who noted the concentration of $E$. coli and coliform to be $5.2 \pm 1.3$ and $6.1 \pm 1.1 \mathrm{CFUg}^{-1}$ respectively in manure as well as Moriarty et al. [43], showed the initial levels of E. coli in cattle faeces to be $7.61 \pm 1.57 \mathrm{CFUg}^{-1}$. The results showed that the relatively high temperature range in the conventional heap was not reflected in shortening the $\mathrm{T}_{90}$ values compared to other treatment strategies. These findings contrast other authors, who reported temperature increase in the heap to effectively facilitate inactivation of pathogens; Larney et al. [2] showed declination of $99.9 \%$ of $E$. coli and coliforms in the first 7 days in manure which were constantly heated at $33.5^{\circ} \mathrm{C}$ to $41.5^{\circ} \mathrm{C}$; Turner [4] reported $E$. coli reduction in two hours at $55^{\circ} \mathrm{C}$; while Kudva et al. [8] described the fluctuation of temperature $\left(-20,4,23,37,45\right.$ and $\left.70^{\circ} \mathrm{C}\right)$ during waste storage to influence the survival of $E$. coli $\mathrm{O} 157$ and the survival was shorter at high temperature. However, Tiquia [9] explained the inactivation to be associated not only with temperature, but with other factors such as moisture contents, microbial mass, the carbon and nitrogen levels in the heap. It is here argued that this study was worth undertaking since it presents the farmers practices whereas other workers on the declination of bacteria either inoculated the study organisms under controlled environmental factors.

According to the current study, it might be argued that ambient temperature in tropical areas, such as the location where this study was carried out is relatively high; this could cause interaction of other factors such as moisture loss to play a significant role on reduction of the faecal indicator bacteria in the waste. However, the argument on the increase of temperature could not be substantiated by the results of the \% $\mathrm{DM}$, since there was no statistical significant difference within four treatment and both seasons. It is therefore speculated that the rapid inactivation of the study organisms in the aerated heap could be attributed to the optimal aeration, which caused accelerated loss of water and desiccation of the manure in the cubes a condition into which $E$. coli, other coliforms and coliphages could not tolerate. The survival of enteric bacteria within animal faeces is also influenced by water content [44-46]. Wang et al. [44] described the effect of moisture content on $E$. coli and other coliforms to influence their counts, the authors reported higher counts $\left(3.52 \log _{10}\right)$ when the moisture content was $83 \%$, but the counts were lowest $(2.05$ $\log _{10}$ ) when the moisture content was $30 \%$ at $27^{\circ} \mathrm{C}$. The authors noted that there is significant interaction between moisture content and temperature, the finding which contrasts the study by Himathongkham et al. [47] who claimed that there is lack of interaction between the two factors.

In the study by Sinton et al. [45] on the survival of indicator bacteria in faeces spread on pastures, it was noted that the water content of 70 to $75 \%$ decreases the numbers of $E$. coli in summer from $3.0^{*} 10^{6}$ to $2.9 * 10^{4} \mathrm{CFUg}^{-1}$ after 141 days. Furthermore the authors explained that sunlight could have contributed to the initial increase and final decrease of these bacteria, by first increasing the optimal temperature for the bacteria multiplication but later on causing the dehydration of the faeces through heat generation. Oliver and Page [46] explored the effect of dehydration of bovine faeces by setting the threshold of $17 \%$ DM content and concluded that E. coli can survive optimally when the $\% \mathrm{DM}$ in the wastes is less than $20 \%$ above which their activity is significantly diminished. In this study the initial mean value of the DM was $20.02 \%$ which is in accordance with the survival of most faecal indicator bacteria in animal wastes. According to the treatments strategies in this study, the \%DM content was relatively higher in aerated heap (Table 1) in both seasons. These findings could be used to explain the hypothesis that dehydration accelerates declination time of faecal indicator bacteria in animal wastes.

The mean $\mathrm{T}_{90}$ value in the aerated heap for $E$. coli (3.1 days) is in comparable to Hutchison et al. [32] who reported a $\mathrm{T}_{90}$ value of 2.31 and 1.47 days following inoculation of $E$. coli $\mathrm{O} 157$ into solid wastes from dairy and beef cattle. Olsen and Larsen [48] obtained $\mathrm{T}_{90}$ of 1.8 days in cattle slurry following E. coli serovar O8 inoculation when the manure were stored at $35^{\circ} \mathrm{C}$ under anaerobic digestion. Ravva et al. [49] who reported the decimation time of $0.5-9.4$ days in native $E$. coli in dairy cattle. However the findings are relatively lower on comparison to Wang et al. [44] who reported declination of $E$. coli $\mathrm{O} 157: \mathrm{H} 7$ to be 45.5 days on average at constant temperature of $37^{\circ} \mathrm{C}$. The work by Nyberg et al. [6] showed the $\mathrm{T}_{90}$ of $E$. coli $\mathrm{O} 157$ from $6.2 \pm 0.3 \log _{10}$ to $2 \log _{10}$ CFU/g dry weight soil within 60 days in detection of $E$. coli inactivation in manure amended soil studied in outdoor lysmeters. The $\mathrm{T}_{90}$ values for coliforms and coliphages were in accordance to the study by Sinton et al. [45] who obtained a $T_{90}$ of 6 and 12 days for coliforms and somatic coliphage inactivation respectively when manure was heaped during summer and winter under controlled exposure to environmental factors like temperature and sunlight.

The $\mathrm{T}_{90}$ values observed in this study were generally relatively higher for the coliforms in all treatment strategies compared to $E$. coli. This could be stipulated that coliform group consist of a mixture of diverse organism, some of which are probably more resistant than $E$. coli to the treatment. Basing on this, counting of the coliforms seemed to constitute a simple measure to compare inactivation between treatments. On the other hand, E. coli inactivation in previous studies has been shown to be very similar to the inactivation of other enteropathogens, such as Salmonella, and inactivation of these are thus more relevant from a public health perspective. To our understanding this kind of studies have not previously been carried out in the tropics, while several studies have been carried on the decimation times in temperate climatic zones [8, 32, 48-51].

\section{Conclusion}

Despite animal wastes containing organisms which cause enteric diseases in humans, good management practices in terms of disposal of such wastes are poorly guided in developing countries. This study intended to provide a simple method which imitate farmers practise so as to improve the outcome of storage of livestock faeces before disposal. The 
method achieved 3-4 log reduction in pathogen load before disposal on farm land which is safe to water sources. We recommend the modification of the waste storage by small farmers to allow optimal aeration in the heap. This method is anticipated to be cheaper, user friendly and might constitute an easy way to increase bacterial and enteric viral inactivation in animal waste before their disposal.

\section{Competing Interest}

The authors declare that they have no competing interests.

\section{Acknowledgements}

We are thankful to the Ministry of Foreign affairs of Denmark through the Danish International Development Agency (DANIDA) for financial support (12-P02-TAN). We feel indebted to thank the Morogoro municipal executive director and the Livestock development office for their permission to collect samples and the research permit (SUA/FVM/R. 1/9) given by the postgraduate research committee of Sokoine University of Agriculture. Furthermore, we thank the Principal of the College of Veterinary and Biomedical Sciences for the permission to use the laboratory during the research period.

\section{References}

[1] Adam, M. (2001). Definition and boundaries of the peri-urban interface: patterns in the patchwork. Waste Composting for Urban and Peri-Urban Agriculture: Closing the Rural-Urban Nutrient Cycle in Sub-Saharan Africa, Ed. Drechsel, P.; Kunze, D., 193-208.

[2] Larney, F. J., Yanke, L. J., Miller, J. J. and Mcallister, T. A. (2003). Fate of Coliform Bacteria in Composted Beef Cattle Feedlot Manure. Journal of Environmental Quality 32 (1995): $1508-1515$

[3] Sorathiya, L. M., Fulsoundar, A. B., Tyagi, K. K., Patel, M. D. and Singh, R. R. (2014). Eco-friendly and modern methods of livestock waste recycling for enhancing farm profitability. International Journal of Recycling of Organic Waste in Agriculture 3 (50): 1-7. doi.org/10.1007/s40093-014-0050-6.

[4] Turner, C. (2002). The thermal inactivation of E. coli in straw and pig manure. Bioresource Technology 84: 57-61.

[5] Alekshun, M. N., Levy, S. B., Angeletti, S., Lorino, G., Gherardi, G., Battistoni, F. et al. (2007). Isolation and selection of coliphages as potential biocontrol agents of enterohemorrhagic and Shiga toxin-producing E. coli (EHEC and STEC) in cattle. Applied and Environmental Microbiology 38 (4): 701-706. doi.org/10.1099/ijs.

[6] Nyberg, K. A., Vinnerås, B., Ottoson, J. R., Aronsson, P. and Albihn, A. (2010). Inactivation of Escherichia coli O157:H7 and Salmonella Typhimurium in manure-amended soils studied in outdoor lysimeters. Applied Soil Ecology 46 (3): 398-404. doi.org/10.1016/j.apsoil.2010.10.004.

[7] Nicholson, F. A., Groves, S. J. and Chambers, B. J. (2005). Pathogen survival during livestock manure storage and following land application. Bioresource Technology 96: 135143.
[8] Kudva, I. T., Blanch, K. and Hovde, C. J. (1998). Analysis of Escherichia coli O157: H7 Survival in Ovine or Bovine Manure and Manure Slurry 64 (9): 3166-3174.

[9] Tiquia, S. M. (2005). Microbiological parameters as indicators of compost maturity. Journal of Applied Microbiology 99 (4): 816-28. doi.org/10.1111/j.1365-2672.2005.02673.x.

[10] Pell, A. N. (1997). Manure and microbes: public and animal health problem? Journal of Dairy Science 80 (10): 2673-81. doi.org/10.3168/jds. S0022-0302.

[11] Hutchison, M. L., Walters, L. D., Moore, A., Crookes, K. M. and Avery, S. M. (2004b). Effect of Length of Time before Incorporation on Survival of Pathogenic Bacteria Present in Livestock Wastes Applied to Agricultural Soil. Applied and Environmental Microbiology 70 (9): 5111-5118. doi.org/10.1128/AEM.70.9.5111.

[12] Yamada, T., Miyauchi, K., Ueda, H., Ueda, Y., Sugawara, H., Nakai, Y. and Endo, G. (2007). Composting cattle dung wastes by using a hyperthermophilic pre-treatment process: characterization by physicochemical and molecular biological analysis. Journal of Bioscience and Bioengineering 104 (5): 408-15. doi.org/10.1263/jbb.104.408.

[13] Donnison, A. M. and Ross, C. M. (1999). Animal and human faecal pollution in New Zealand rivers. New Zealand Journal of Marine and Freshwater Research 33 (1): 119-128. doi.org/10.1080/00288330.1999.9516862.

[14] Rompré, A., Servais, P., Baudart, J., De-Roubin, M. R. and Laurent, P. (2002). Detection and enumeration of coliforms in drinking water: Current methods and emerging approaches. Journal of Microbiological Methods 49 (1): 31-54. doi.org/10.1016/S0167-7012(01)00351-7.

[15] Hagens, S. and Loessner, M. J. (2007). Application of bacteriophages for detection and control of foodborne pathogens. Applied Microbiology and Biotechnology, 76 (3), 513-519. doi.org/10.1007/s00253-007-1031-8.

[16] WHO. (2002). The World Health report 2002 - reducing risks, promoting healthy life. Education for Health (Abingdon, England) 16 (2): 230. http://doi.org/10.1080/.

[17] ISO (International Standards Organisation). (2004). Microbiology of food and animal feeding stuffs - Horizontal methods for the detection and enumeration of Enterobacteriaceae - Part 2: Colony-count method. www.iso.org/standards-catalogue/browse-by-ics.

[18] Dini, C. and De Urraza, P. J. (2010). Isolation and selection of coliphages as potential biocontrol agents of enterohemorrhagic and Shiga toxin-producing E. coli (EHEC and STEC) in cattle. Journal of Applied Microbiology 109 (3): 873-887. doi.org/10.1111/j.1365-2672.2010.04714.x.

[19] Syngouna, V. I. and Chrysikopoulos, C. V. (2014). Bacteriophages as faecal indicators in environmental systems: Historical perspectives and recent uses Bacteriophages as indicators. In IWA Regional Symposium on Water, Wastewater and Environment: Traditions and Culture Patras, Greece (pp. 22-24).

[20] Muniesa, M., Lucena, F. and Jofre, J. (1999). Study of the potential relationship between the morphology of infectious somatic coliphages and their persistence in the environment. Journal of Applied Microbiology 87 (3): 402-409. doi.org/10.1046/j.1365-2672.1999.00833.x.

[21] Grabow, W. O. K. (2001). Bacteriophages: Update on application as models for viruses in water. Water SA 27 (2): 251-268. http://doi.org/10.4314/wsa.v27i2.4999. 
[22] Jofre, J., Lucena, F., Blanch, A. R. and Muniesa, M. (2016). Coliphages as model organisms in the characterization and management of water resources. Water (Switzerland). Multidisciplinary Digital Publishing Institute. doi.org/10.3390/w8050199.

[23] Oot, R. A, Raya, R. R., Callaway, T. R., Edrington, T. S., Kutter, E. M. and Brabban, A. D. (2007). Prevalence of Escherichia coli $\mathrm{O} 157$ and O157:H7-infecting bacteriophages in feedlot cattle faeces. Letters in Applied Microbiology 45 (4): 445-53. doi.org/10.1111/j.1472-765X.2007.02211.x.

[24] Callaway, T. R., Edrington, T. S., Brabban, A. D., Anderson, R. C., Rossman, M. L., Engler, M. J., Nisbet, D. J., et al. (2008). Bacteriophages Isolated from Feedlot Cattle Can Reduce Escherichia coli O157:H7 Populations in Ruminant Gastrointestinal Tracts. Foodborne Pathogens and Disease 5 (2): 183-191.

[25] Niu, Y. D., Mcallister, T. A., Xu, Y., Johnson, R. P., Stephens, T. P. and Stanford, K. (2009). Prevalence and Impact of Bacteriophages on the Presence of Escherichia coli O157:H7 in Feedlot Cattle and Their Environment. Applied and Environmental Microbiology 75 (5): 1271-1278. doi.org/10.1128/AEM.02100-08.

[26] Lupindu A. M, Ngowi H. A, Dalsgaard A, Olsen, J. E. and MSoffe, P. L. M. (2012). Current manure management practices and hygiene aspects of urban and peri-urban livestock farming in Tanzania. Livestock Research and Rural Development 24 (167).

[27] Madoshi, B. P., Lupindu, A. M., Mtambo, M. M. A., Muhairwa, A. P. and Olsen, J. E. (2017). Factors Associated with Acquisition of Enteric Episodes in Cattle Waste Handlers in Morogoro, Tanzania. Bulletin of Animal Health and Production in Africa 65 (1): 7-15.

[28] Mahfooz, S., Saghir, A. S. and Ashar, A. (2006). Composting: A Unique Solution to Animal Waste Management. Journal of Agriculture and Social Sciences 2 (1): 38-41.

[29] ISO (International Standards Organisation). (2000). Water quality -- Detection and enumeration of bacteriophages -- Part 2: Enumeration of somatic coliphages. doi.org/ISO 10705-2:2000.

[30] Adams, M. H. (1959). Bacteriophages. Bacteriophages. (New York and London): Inter-science Publishers. http://doi.org/19602204111.

[31] Forslund, A., Markussen, B., Toenner-Klank, L., Bech, T. B., Jacobsen, O. S. and Dalsgaard, A. (2011). Leaching of Cryptosporidium parvum oocysts, Escherichia coli, and Salmonella enterica serovar Typhimurium bacteriophage through intact soil cores following surface application and injection of slurry. Applied and Environmental Microbiology 77 (22): 8129-38. doi.org/10.1128/AEM.05675-11.

[32] Hutchison, M. L., Walters, L. D., Avery, S. M. and Moore, A. (2005b). Decline of zoonotic agents in livestock waste and bedding heaps. Journal of Applied Microbiology 99 (2): 35462. doi.org/10.1111/j.1365-2672.2005.02591.x.

[33] Corradini, M. G. and Peleg, M. (2009). Dynamic model of heat inactivation kinetics for bacterial adaptation. Applied and $\begin{array}{llll}\text { Environmental Microbiology } 75 & \text { (8): } 2590-2597 .\end{array}$ doi.org/10.1128/AEM.02167-08.

[34] Osawa, S., Furuse, K. and Watanabe, I. (1981). Distribution of ribonucleic acid coliphages in animals. Distribution of Ribonucleic Acid Coliphages in Animals 41 (1): 164-168.

[35] Muniesa, M., Mocé-Llivina, L., Katayama, H. and Jofre, J.
(2003). Bacterial host strains that support replication of somatic coliphages. Antonie van Leeuwenhoek, International Journal of General and Molecular Microbiology 83 (4): 305-315. doi.org/10.1023/A:1023384714481.

[36] Lucena, F., Ribas, F., Duran, A. E., et alSkraber, S., Gantzer, C., Campos, C. et al. (2006). Occurrence of bacterial indicators and bacteriophages infecting enteric bacteria in groundwater in different geographical areas. Journal of Applied Microbiology 101 (1): 96-102. doi.org/10.1111/j.1365-2672.2006.02907.x.

[37] Dhillon, T. S., Dhillon, E. K. S., Chau, H. C., Li, W. K. and Tsang, A. H. C. (1976). Studies on Bacteriophage Distribution: Virulent and Temperate Bacteriophage Content of Mammalian Feces. Applied and Environmental Microbiology, 32 (1): 6874.

www.ncbi.nlm.nih.gov/pmc/articles/PMC170007/pdf/aem0000 6-0080.pdf.

[38] Jung, E. L., Mi, Y. L., Sei, Y. K. et al. (2009). Molecular characterization of bacteriophages for microbial source tracking in Korea. Applied and Environmental Microbiology 75 (22): 7107-7114. doi.org/10.1128/AEM.00464-09.

[39] Cunault, C., Pourcher, A. M. and Burton, C. H. (2011). Using temperature and time criteria to control the effectiveness of continuous thermal sanitation of piggery effluent in terms of set microbial indicators. Journal of Applied Microbiology 111 (6): 1492-1504. doi.org/10.1111/j.1365-2672.2011.05144.x.

[40] Pesaro, F., Sorg, I. and Metzler, A. (1995). In situ inactivation of animal viruses and a coliphage in nonaerated liquid and semiliquid animal wastes. Applied and Environmental Microbiology 61 (1): 92-97.

[41] Thurston-Enriquez, J. A., Gilley, J. E. and Eghball, B. (2005). Microbial quality of runoff following land application of cattle manure and swine slurry. Journal of Water and Health 3 (2): $157-171$.

[42] Klein, M., Brown, L., Tucker, R. W., Ashbolt, N. J., Stuetz, R. M. and Roser, D. J. (2010). Diversity and abundance of zoonotic pathogens and indicators in manures of feedlot cattle in Australia. Applied and Environmental Microbiology 76 (20): 6947-6950. doi.org/10.1128/AEM.01095-10.

[43] Moriarty, E. M., Mackenzie, M. L., Karki, N. and Sinton, L. W. (2011). Survival of Escherichia coli, Enterococci, and Campylobacter spp. in sheep feces on pastures. Applied and Environmental Microbiology 77 (5): 1797-1803. doi.org/10.1128/AEM.01329-10.

[44] Wang, L., Mankin, K. R. and Marchin, G. L. (2004). Survival of Fecal Bacteria in Dairy Cow Manure. Transactions of the ASAE 47 (4): 1239-1246.

[45] Sinton, L. W., Braithwaite, R. R., Hall, C. H. and Mackenzie, M. L. (2007). Survival of indicator and pathogenic bacteria in bovine feces on pasture. Applied and Environmental Microbiology $\quad 73 \quad$ (24): 7917-7925. doi.org/10.1128/AEM.01620-07.

[46] Oliver, D. M. and Page, T., (2016). Effects of seasonal meteorological variables on $E$. coli persistence in livestock faeces and implications for environmental and human health. Nature Publishing Group 6 (7): 1-10. doi.org/10.1038/srep37101.

[47] Himathongkham, S., Bahari, S., Riemann, H. and Cliver, D. (1999). Survival of Escherichia coli O157:H7 and Salmonella typhimurium in cow manure and cow manure slurry. FEMS Microbiology Letters 178 (1999): 251-257. doi.org/10.1111/j.1574-6968.1999.tb08684.x. 
[48] Olsen, J. E. and Larsen, H. E. (1987). Bacterial decimation times in anaerobic digestions of animal slurries. Biological Wastes 21 (3): 153-168. doi.org/10.1016/0269-7483.

[49] Ravva, S. V., Sarreal, C. Z., Duffy, B. and Stanker, L. H. (2006) Survival of Escherichia coli O157:H7 in wastewater from dairy lagoons. Journal of Applied Microbiology 101 (4): 891-902. doi.org/10.1111/j.1365-2672.2006.02956.x.
[50] Villar, I., Alves, D., Garrido, J. and Mato, S. (2016). Evolution of microbial dynamics during the maturation phase of the composting of different types of waste. Waste Management 54: 83-92. doi.org/10.1016/j.wasman.2016.05.011.

[51] Zhang, T., Wang, H., Wu, L., Lou, J., Wu, J., Brookes, P. C. and $\mathrm{Xu}$, J. (2013). Survival of Escherichia coli O157:H7 in soils from Jiangsu province, China. $\mathrm{P}$ LoSone 8 (12). doi.org/10.1371/journal.pone.0081178. 